\title{
THE PERFORMANCE OF GRAPHITE/N-GRAPHENE AND GRAPHENE/N-GRAPHENE AS ELECTRODE IN PRIMARY CELL BATTERIES
}

\author{
D. Ratih ${ }^{1}$, R. Siburian ${ }^{2,3, *}$ and Andriayani ${ }^{2}$ \\ ${ }^{1}$ Post-Graduate School-Chemistry Department, University of Sumatera Utara, \\ Medan-20155, Indonesia \\ ${ }^{2}$ Chemistry Department, University of Sumatera Utara, Medan-20155, Indonesia \\ ${ }^{3}$ Nano medicine center, University of Sumatera Utara, Medan-20155, Indonesia \\ "E-mail: riksonsiburian2000@yahoo.com
}

\begin{abstract}
Research about the performance of Graphite/N-Graphene and Graphene/N-Graphene as the cathode of primary used modified Hummers and impregnation methods was carried out. Characterization of materials was characterized by using XRD, FTIR, SEM-EDX and Conductometry, respectively. XRD data show that $\mathrm{N}$ atoms were well be deposited on Graphene to form N-Graphene, it was indicated by the weak peak was appear at $2 \theta=26.16^{\circ}$. This data was consistent with EDX data where $\mathrm{N}$ atoms existed on $\mathrm{N}-$ Graphene (2.72\%). FTIR data broad definitely confirm that there is an interaction between $\mathrm{C}$ and $\mathrm{N}$ (peak at $1396 \mathrm{~cm}^{-1}$ ). The conductivity data showed that N-Graphene has higher conductivity value $(1157.32 \mu \mathrm{S} / \mathrm{cm})$. Meanwhile, the conductivity of Graphite/N-Graphene (1:2) is higher (350.20 $\mu \mathrm{S} / \mathrm{cm})$ compared to the Graphite/N-Graphene (2:1) (102.70 $\mu \mathrm{S} / \mathrm{cm})$ and conductivity of Graphene/NGraphene (1:2) is higher $(969.33 \mu \mathrm{S} / \mathrm{cm})$ compared to the Graphene/N-Graphene (2:1) $(878.18 \mu \mathrm{S} / \mathrm{cm})$. All data prove that $\mathrm{N}$-Graphene may increase the performance of Graphite/N-Graphene and Graphene/N-Graphene on cathode's primary battery.
\end{abstract}

Keywords: Graphene, Graphite, Cathode's primary battery, Hummers's method, Impregnation methods, NGraphene

(C) RASĀYAN. All rights reserved

\section{INTRODUCTION}

Batteries have now become part of everyday life especially those related to electronic devices. The components of the primary battery were the zinc $(\mathrm{Zn})$ as anode carbon rods as a cathode, and mixed pastes $\mathrm{MnO}_{2}$, carbon powder and $\mathrm{NH}_{4} \mathrm{Cl}$ as electrolyte ${ }^{1}$. Primary batteries are widely used, evident from total consumer demand of 521,470,407 in 2007 and in 2010 the capacity of dry manganese-based battery production increased to 2 million units per year.

Graphene is a graphite monolayer, which consists of $\mathrm{sp}^{2}$ hybridization of carbon atoms having hexagonal structures and arranged in a honeycomb crystal lattice ${ }^{2}$. In the electrochemical surface oxidation route, high-quality graphene oxide was produced on the surface of the graphite $\operatorname{rod}^{3}$. Graphene oxide is synthesized through the chemical route where the presence of various oxygen functional groups is identified $^{4}$. Graphene can be produced via sulfur intercalated and thermal exfoliation method and it was used for the fabrication of modified electrode ${ }^{5}$. Graphene becomes one of the ideal materials that can be applied to various fields of technology $y^{6}$, eg fuel cells ${ }^{7}$, capasitor ${ }^{8}$, sensor, rechargeable battery and supercapasitor ${ }^{9}$, transparent electrode ${ }^{10}$, the strength of $\mathrm{Al}-7075^{11}$ and elektrocatalysis ${ }^{12}$. Graphene has a weakness like having a strange ribbon structure, valence band $(\pi)$ and conduction $\left(\pi^{*}\right)$ are not separated (linear) so that graphene has no energy gap (zero gaps) and graphene without metals shows low activity ${ }^{13}$. Graphene needs to be modified to modulate the electronic properties of graphene. One way is to deflate graphene (defect of graphene). Graphene defect can be done by inserting new materials such as nitrogen into graphene (N-Graphene) ${ }^{14}$. N-doping carbon can increase the electronic conductivity due to the

Rasayan J. Chem., 11(4), 1649-1656(2018)

http://dx.doi.org/10.31788/RJC.2018.1145007

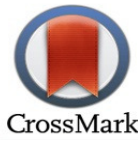


formation of variations of the $\mathrm{N}$-doping structure ${ }^{15}$. Thus, the electronic performance and catalytic activities can be improved with $\mathrm{N}$-Graphene ${ }^{16,17}$. Modification of carbon materials especially with the use of nitrogen ( $\mathrm{N}$-carbon dopant) has been proposed as a metal-free electrode material ${ }^{18}$ and could be used as a supporting material as an electrode in the primary battery cell.

\section{EXPERIMENTAL}

\section{Material and Methods}

Graphite commercial powder (carbon $98 \mathrm{wt} \%$, ash wt $15 \%$ ), sulfuric acid $\left(\mathrm{H}_{2} \mathrm{SO}_{4}, 98 \mathrm{wt} \%\right)$, potassium permanganate $\left(\mathrm{KMnO}_{4}, 99.5 \mathrm{wt} \%\right)$, hydrogen peroxide $\left(\mathrm{H}_{2} \mathrm{O}_{2}, 30 \mathrm{wt} \%\right)$ and ammonia $\left(\mathrm{NH}_{3}, 25 \mathrm{wt} \%\right)$ were purchased from Sigma-Aldrich (Singapore). Sodium Nitrate $\left(\mathrm{NaNO}_{3}, 99 \mathrm{wt} \%\right)$ was purchased from Merck (Singapore). All the chemical reagents as approved without any further purification. The performance of Graphite/N-Graphene and Graphene/N-Graphene as the cathode of primary used modified Hummers and impregnation methods.

\section{General Procedure}

\section{Synthesis of Graphene Oxide}

Graphene Oxide was synthesized base on graphite powder by using a modification of Hummers and Offenman's method ${ }^{19}$. Briefly, $4 \mathrm{~g}$ of graphite was added with $4 \mathrm{~g} \mathrm{NaNO}_{3}$ and $300 \mathrm{ml} \mathrm{H}_{2} \mathrm{SO}_{4}$, were stirred together for 4 hours in an ice bath condition. The end of 4 hours, 20 grams of $\mathrm{KMnO}_{4}$ was slowly added into the solution and stirred for 4 days to generate graphite solution. Finally, $400 \mathrm{~mL}$ of $\mathrm{H}_{2} \mathrm{SO}_{4} 5 \%$ and 20 $\mathrm{mL} \mathrm{H}_{2} \mathrm{O}_{2} 30 \%$, stirred for 4 hours, respectively. The solution was centrifuged at 72,000 rpm for 10 minutes and ultrasonication for 6 hours, croping a solution of graphene oxide.

\section{Synthesis of Graphene}

The producing graphene oxide solution was to be shared into two parts, the first solution was dried with an oven at $80^{\circ} \mathrm{C}$ to result in the graphene oxide powder. The different solution was added with a $1 \mathrm{~mL}$ of $\mathrm{NH}_{3} 10 \mathrm{M}$ and stirred for 72 hours, filtered and dried at $80^{\circ} \mathrm{C}$ to produce graphene powder.

\section{Synthesis of N-Graphene}

The explanation, $\mathrm{N}-$ Graphene was synthesized follow as: Graphene solution was added $10 \mathrm{~mL} \mathrm{NH} 310 \mathrm{M}$ and stirred for 48 hours. Then, the solution was filtered and dried at $80^{\circ} \mathrm{C}$ to product $\mathrm{N}$-Graphene powder.

\section{Preparation of Electrodes in Primary Cell Battery}

Preparation of electrodes in primary cell battery was performed on various variations in grams of 1:1, 2:1 and 1:2 in Graphite/N-Graphene and Graphene/N-Graphene. In the comparison variation Graphite/NGraphene 1:1 by weighing 1 gram of graphite and $\mathrm{N}$-graphene, each added $50 \mathrm{ml}$ of aquadest and stirred for 1 hour. Then the graphite/aquadest and graphene/aquadest solution were mixed and stirred again for 2 hours. The solution was filtered and dried at $\mathrm{T}=80^{\circ} \mathrm{C}$. The similar way was done on the variation of Graphite/N-Graphene 1:2 and 2:1 composition and graphene/N-Graphene 1:2 and 2:1 composition.

\section{Characterization Method}

All of the samples (graphite, graphene oxide, graphene, cathode's primary battery (commercial) and NGraphene were analyzed by using X-Ray Diffraction (XRD), Fourier Transform Infrared (FTIR), Scanning Electron Microscope-Energy Dispersive X-Ray (SEM-EDX) and conductometer, respectively. X-Ray diffraction (XRD) analysis used X-Ray Rigaku Smartlab $3 \mathrm{~kW}$. Cu-Ka radiation (1.540598 A) was used to observe samples from 5 to $80^{\circ}$ of $2 \theta$ (degree), scanning speed $2 \% \mathrm{~min}, 44 \mathrm{kV}$, and $40 \mathrm{~mA}$ current. Fourier Transform Infrared (FTIR) spectra were recorded on Shimadzu IR Prestige-21. All of FTIR spectra were recorded in the transmittance mode with a range of $4000-500 \mathrm{~cm}^{-1}$. SEM-EDX analysis used type of EM 30 COXEM with a voltage of 20,000 kV with enlargement 100-4000 times. Conductometer analyzed used a type of AC780-Conductivity Meter i-SOLV at room temperature.

\section{XRD Analysis}

\section{RESULTS AND DISCUSSION}

X-ray diffraction (XRD) pattern of Graphite, Graphene Oxide, Graphene and N-Graphene were showed by Fig.-1. Graphite structure analysis having a sharp and tight diffraction peak at $26.56^{\circ}$ which 
RASĀYAN J. Chem.

Vol. 11 | No. 4 |1649 - 1656| October - December | 2018

corresponds to the diffraction line $\mathrm{C}(002)$ with the intercellular spacing in the crystal having a d-spacing of $3.37 \AA$, as reported previously ${ }^{20}$.
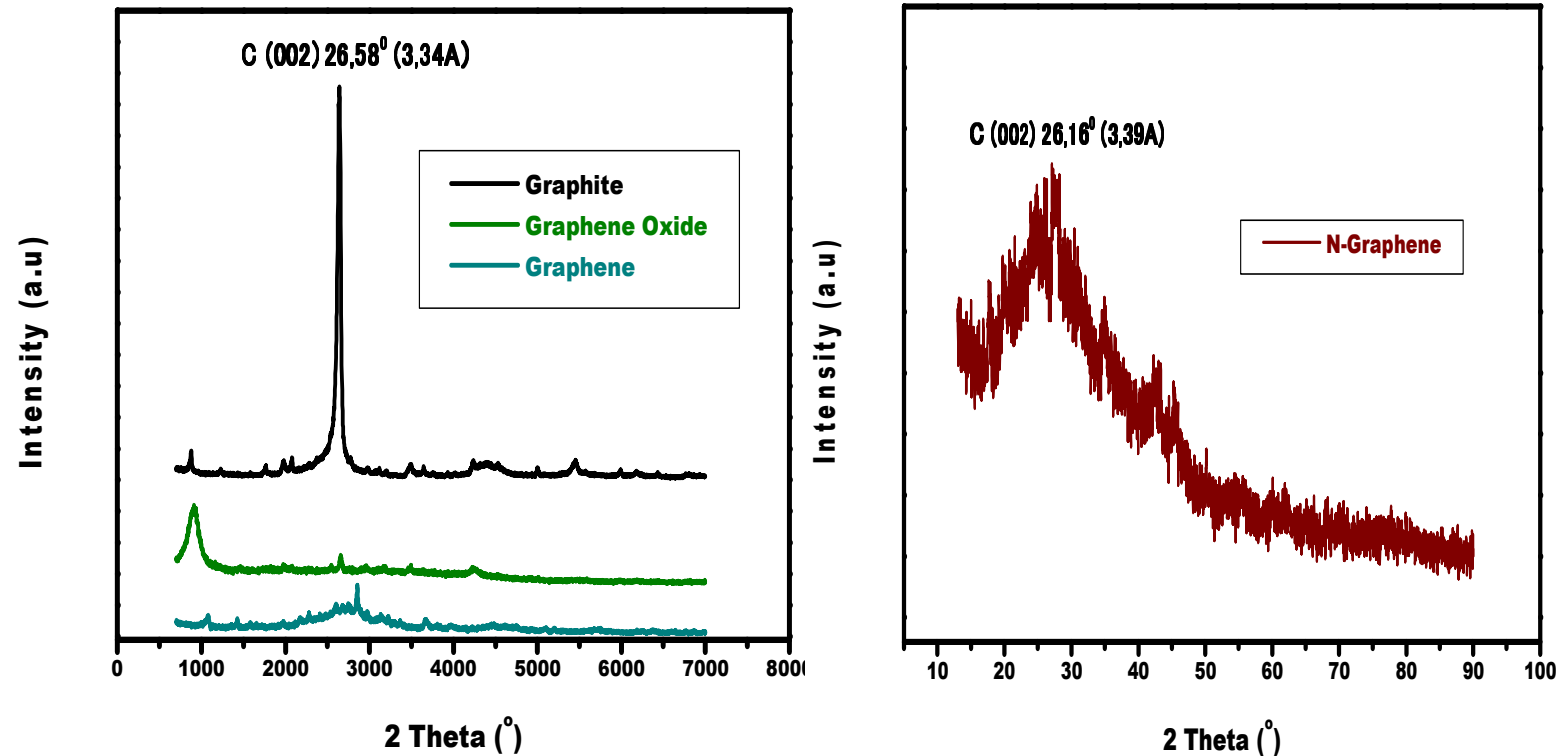

Fig.-1: XRD patterns of Graphite, Graphene Oxide, Graphene and N-Graphene.

A sharp diffraction peak at $2 \theta=9.07^{\circ}$ having a d-spacing $9.74 \AA$ shows that graphite has been oxidized producing graphene oxide, as reported previously ${ }^{21}$. Ascending the distance between fields in the graphene oxide results in existence oxygen functional group and water molecule into the carbon layer structure $^{22}$. The resulting of the reduction graphene have a sharp diffraction peak at $2 \theta=26.52^{\circ}$ having a dspacing $3.35 \AA$. The shifting of $2 \theta$ to the right occurring at the time of deformation of graphene oxide to graphene due to loss of phenol, epoxy, ketone, carboxyl and carbonyl groups in graphene oxide due to the role of ammonia $\left(\mathrm{NH}_{3}\right)$.

Graphene has a structure between the crystalline and amorphous structures. This is proofed by the emergence of the diffraction line $\mathrm{C}(002)$ which looks wider and the intensity is lower than the peak obtained in the graphite powder.

$\mathrm{N}$-graphene revealed a slight broad peak centered at $26.16^{\circ}$ having a d-spacing of $3.39 \AA$, which confirms the recovery of the graphitic crystal ${ }^{21}$. Doping heteroatom $(\mathrm{N})$ in graphene induces site defects and destruction in the carbon lattice, this result caused $\mathrm{N}$-graphene to have low crystallinity and causing a small shifting in the value of $2 \theta .^{23}$
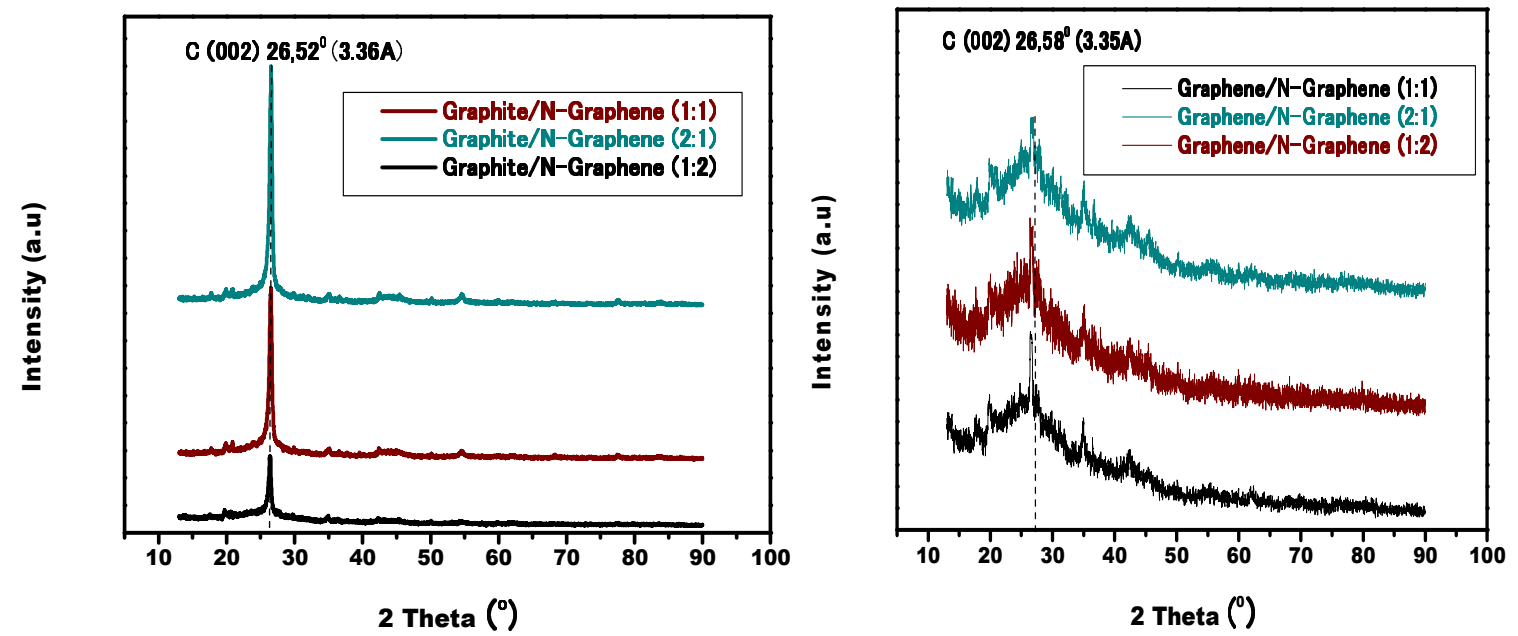

Fig.-2: XRD patterns of Graphite/N-Graphene and Graphene/N-Graphene 
RASĀYAN J. Chem.

Vol. 11 | No. 4 |1649 - 1656| October - December | 2018

The resulting of the XRD analysis on graphite/N-Graphene 1:1 and 2:1 has a sharp peak, meaning the peak of the more dominant graphite ${ }^{24}$ were shown by Fig.-2. While on the variation of ratio Graphene/NGraphene (1:2) causes a shifting in the value position $2 \theta$ toward the N-Graphene diffraction peak. This is due to the presence of new materials such as Nitrogen that enters into the interlayer space of the graphene resulting in interaction between $\mathrm{C}-\mathrm{N}$ and rearrangement of structures graphene.

\section{FTIR Analysis}

All of FTIR spectra were recorded in the transmittance mode in the range of $4000-500 \mathrm{~cm}^{-1}$.

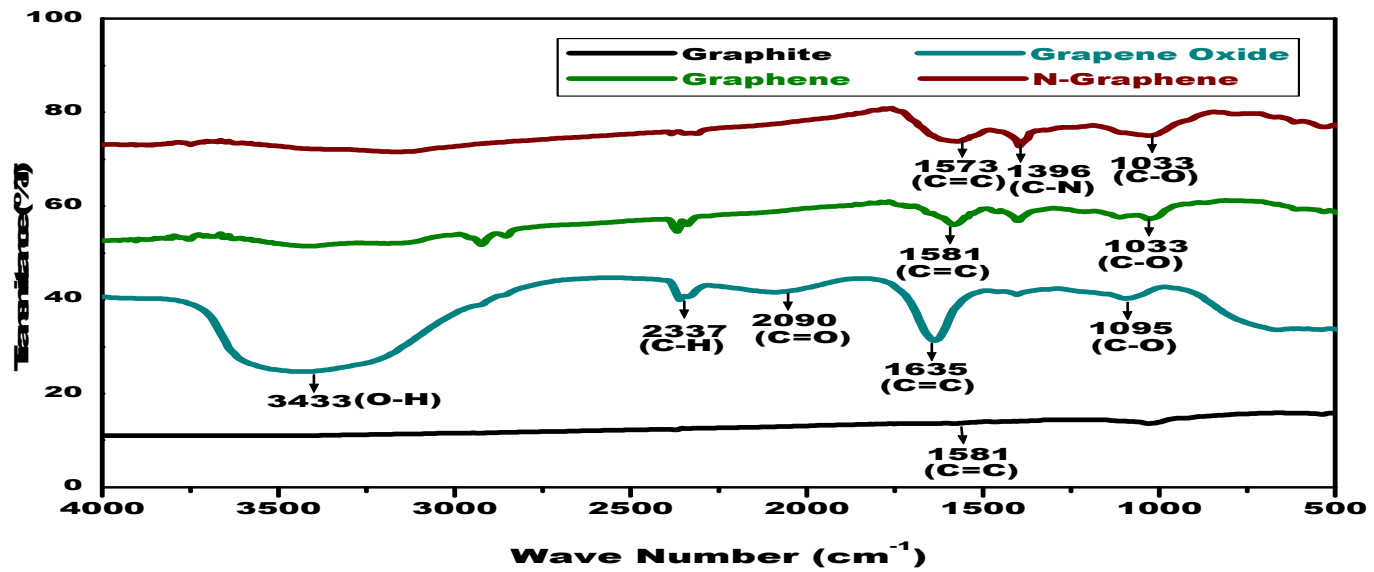

Fig.-3: FTIR Data of Graphite, Graphene Oxide, Graphene and N-Graphene

Fourier Transform Infra Red (FTIR) spectra of graphite, graphene oxide, graphene and N-Graphene were shown by Fig.-3. Graphite powder has a peak obtained at $1581 \mathrm{~cm}^{-1}$ show vibration of $\mathrm{C}=\mathrm{C}$ aromatic. The synthesized graphene oxide from graphite flakes consists of various oxygen functional group and attributed to the $\mathrm{O}-\mathrm{H}$ stretching vibration at $3433 \mathrm{~cm}^{-1}$ and $\mathrm{C}=\mathrm{O}$ stretching vibration at $2090 \mathrm{~cm}^{-1}$. The peak on the surrounding area $1203 \mathrm{~cm}^{-1}, 1050 \mathrm{~cm}^{-1}$ show vibrational deformation C-O epoxy, and C-O alkoxy, respectively ${ }^{25}$. The graphite oxide was chemically reduced with ammonia to result in graphene. After reduction reaction, the peak $1500 \mathrm{~cm}^{-1}$ coresponds to the weak and sharp $\mathrm{C}=\mathrm{C}$ aromatic which is the main bond on the structure of graphene. Whereas vibrational deformation $\mathrm{C}=\mathrm{O}$ (carbonyl), $\mathrm{C}-\mathrm{OH}$ (phenol) and C-O (alkoxy/ether) were diminished. In N-Graphene, the nitrogen atom replaces the carbon atom where there is a peak appeared at 1573, 1396 and $1033 \mathrm{~cm}^{-1}$ in the $\mathrm{N}-$ Graphene correspond to the strong and sharp peak $\mathrm{C}=\mathrm{C}, \mathrm{C}-\mathrm{N}$ and $\mathrm{C}-\mathrm{O}$ stretching bond,respectively. This indicates that $\mathrm{N}$-Graphene is formed $^{26}$.
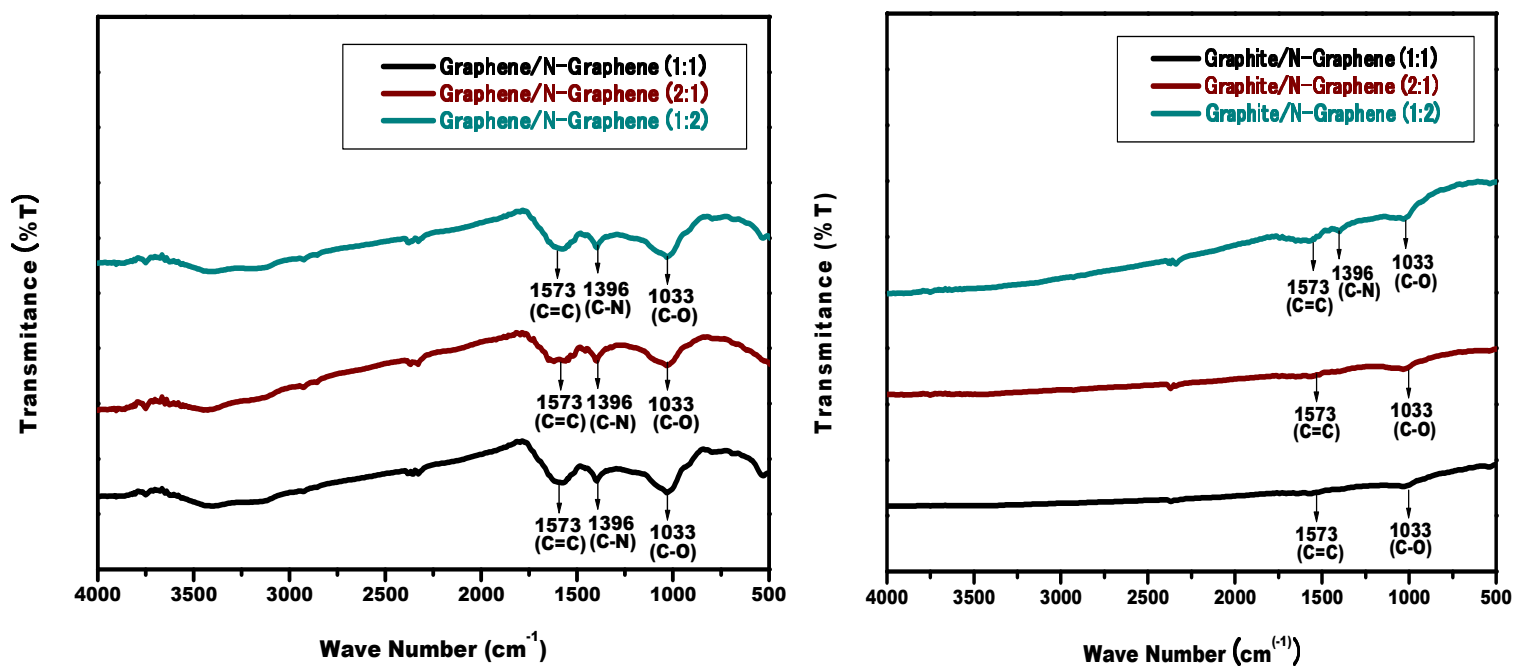

Fig.-4: FTIR data of Graphite/N-Graphene and Graphene/ N-Graphene 
RASĀYAN $J$. Chem.

Vol. 11 | No. 4 |1649 - 1656| October - December | 2018

FTIR spectra of Graphite/N-Graphene and Graphene/N-Graphene were shown by Fig. 4 . The composition variation of the Graphite/N-Graphene 1:1 dan 2:1 has a characteristic peak on $1573 \mathrm{~cm}^{-1}$ show vibration strain from $\mathrm{C}=\mathrm{C}$ aromatically derived from structures on graphite. The FTIR resulting indicates that in the comparison variation of the Graphene/N-Graphene 1:1, 2:1 and 1:2 has a characteristic peak on $1396 \mathrm{~cm}^{-1}$ which indicates a bond C-N. It means doping of nitrogen atoms into the structure of the graphene is succeeding ${ }^{27}$.

\section{SEM-EDX Analysis}

SEM-EDX analysis used type of EM 30 COXEM with a voltage of 20,000 kV with enlargement 100 4000times.
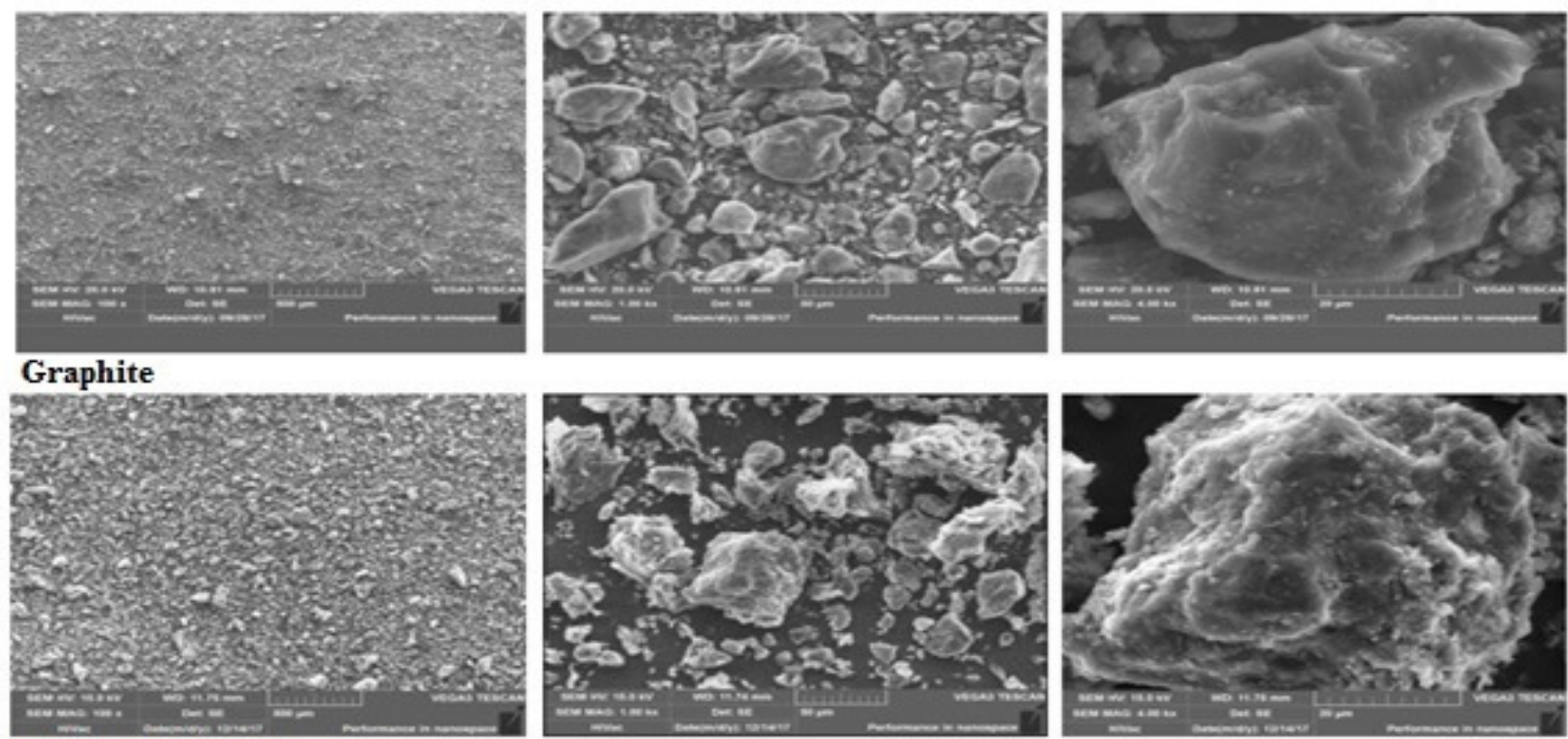

\section{Cathode primary battery}
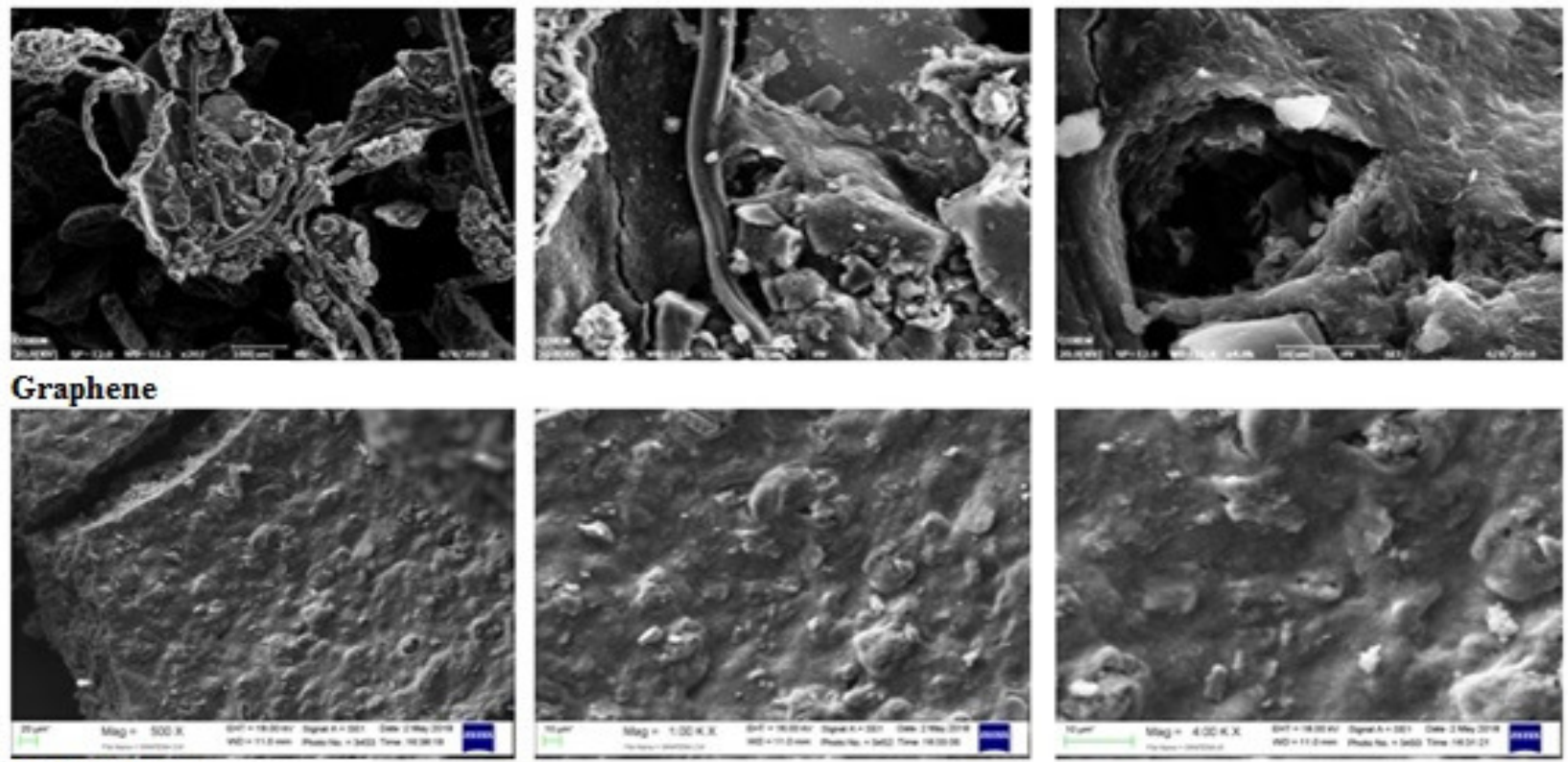

\section{N-Graphene}

Fig.-5: SEM images of Graphite, Cathode's primary battery (commercial), Graphene and N-Graphene with 100× (a), $1000 \times$ (b) and $4000 \times$ magnification (c)

The microstructure of graphite, cathode's primary battery (commercial), graphene and N-Graphene were shown by Fig.-5. Graphite and cathode batteries have thick and wide surfaces as well as visible heap size, indicating that graphite has a layered structure ${ }^{28}$. Graphene has a randomly arranged aggregate with a 
RASĀYAN J. Chem.

Vol. 11 | No. 4 |1649 - 1656| October - December | 2018

thin layer and is tightly linked to one another to form an irregular solid compare graphite and cathode batteries. The morphological shape of $\mathrm{N}$-Graphene has not been a single layer, the suspicion that surfaces are yet more smooth coalesce, and some of them are thin and uniform surfaces ${ }^{29}$.

The composition chemical of Cathode's primary battery (commercial), Graphite, Graphene and NGraphene were characterized by using SEM-EDX. The SEM-EDX data of the cathode's primary battery (commercial) is shown by Table-1.

Table-1: The Results of SEM-EDX Analysis for Cathode's Primary Battery (Commercial)

\begin{tabular}{c|c|c|c}
\hline $\begin{array}{c}\text { Number } \\
\text { Element }\end{array}$ & $\begin{array}{c}\text { Element } \\
\text { Symbol }\end{array}$ & $\begin{array}{c}\text { Element } \\
\text { Nam }\end{array}$ & $\begin{array}{c}\text { Weight } \\
\text { Concentration Element (\%) }\end{array}$ \\
\hline 6 & $\mathrm{C}$ & Carbon & 96.99 \\
\hline 13 & $\mathrm{Al}$ & Aluminum & 0.50 \\
\hline 14 & $\mathrm{Si}$ & Silicon & 0.78 \\
\hline 16 & $\mathrm{~S}$ & Sulfur & 1.11 \\
\hline 26 & $\mathrm{Fe}$ & Iron & 0.62 \\
\hline \multicolumn{4}{r}{ Sum } \\
\hline
\end{tabular}

The SEM-EDX data of the graphite is shown by Table-2.

Table-2: The Results of SEM-EDX Analysis for Graphite

\begin{tabular}{c|c|c|c}
\hline $\begin{array}{c}\text { Number } \\
\text { Element }\end{array}$ & $\begin{array}{c}\text { Element } \\
\text { Symbol }\end{array}$ & $\begin{array}{c}\text { Element } \\
\text { Name }\end{array}$ & $\begin{array}{c}\text { Weight } \\
\text { Concentration Element (\%) }\end{array}$ \\
\hline 6 & $\mathrm{C}$ & Carbon & 84.50 \\
\hline 8 & $\mathrm{O}$ & Oxygen & 12.05 \\
\hline 13 & $\mathrm{Al}$ & Aluminum & 0.83 \\
\hline 14 & $\mathrm{Si}$ & Silicon & 1.06 \\
\hline 16 & $\mathrm{~S}$ & Sulfur & 0.65 \\
\hline 19 & $\mathrm{~K}$ & Potassium & 0.28 \\
\hline 22 & $\mathrm{Ti}$ & Titanium & 0.63 \\
\hline \multicolumn{3}{|c}{ Sum } \\
\hline
\end{tabular}

The SEM-EDX data of the graphene is shown by Table-3.

Table-3: The Results of SEM-EDX Analysis for Graphene

\begin{tabular}{c|c|c|c}
\hline $\begin{array}{c}\text { Number } \\
\text { Element }\end{array}$ & $\begin{array}{c}\text { Element } \\
\text { Symbol }\end{array}$ & $\begin{array}{c}\text { Element } \\
\text { Name }\end{array}$ & $\begin{array}{c}\text { Weight } \\
\text { Concentration Element (\%) }\end{array}$ \\
\hline 6 & $\mathrm{C}$ & Carbon & 75.88 \\
\hline 8 & $\mathrm{O}$ & Oxygen & 8.64 \\
\hline 13 & $\mathrm{Al}$ & Aluminum & 7.5 \\
\hline 16 & $\mathrm{~S}$ & Sulfur & 4.62 \\
\hline 19 & $\mathrm{~K}$ & Potassium & 3.36 \\
\hline \multicolumn{3}{|c|}{ Sum } & 100.00 \\
\hline
\end{tabular}

The SEM-EDX data of the graphite is shown by Table-4. The conductivity of graphite, cathode primary battery (commercial), graphene oxide, graphene, N-Graphene, Graphite/N-Graphene and Graphene/NGraphene are shown in Table-5, respectively.

Table-4: The Result of SEM-EDX Analysis for N-Graphene

\begin{tabular}{c|c|c|c}
\hline $\begin{array}{c}\text { Number } \\
\text { Element }\end{array}$ & $\begin{array}{c}\text { Element } \\
\text { Symbol }\end{array}$ & $\begin{array}{c}\text { Element } \\
\text { Name }\end{array}$ & $\begin{array}{c}\text { Weight } \\
\text { Concentration Element (\%) }\end{array}$ \\
\hline 6 & $\mathrm{C}$ & Carbon & 56.87 \\
\hline 8 & $\mathrm{O}$ & Oxygen & 32.9 \\
\hline 25 & $\mathrm{Mn}$ & Manganese & 4.31 \\
\hline 7 & $\mathrm{~N}$ & Nitrogen & 2.72 \\
\hline 13 & $\mathrm{Al}$ & Aluminum & 1.88 \\
\hline 19 & $\mathrm{~K}$ & Potassium & 0.57 \\
\hline 16 & $\mathrm{~S}$ & Sulfur & 0.47 \\
\hline 11 & $\mathrm{Na}$ & Sodium & 0.28 \\
\hline \multicolumn{4}{|c}{ Sum } \\
\hline
\end{tabular}


The conductivity of $\mathrm{N}-G r a p h e n e$ is greater than that of the amount $1157.33 \mu \mathrm{S} / \mathrm{cm}$, it is due to the modification of the graphene structure due to the addition of nitrogen derived from ammonia which will be donate electrons into the graphene structure so that $\mathrm{N}$-graphene will form the interaction $\mathrm{C}-\mathrm{N}$ in a graphene which is capable of the system can change band gap of graphene and increasing the conductivity of graphene so it is using electrode in primary cell batteries. N-Graphene can be used supercapacitors, solar cells, sensors and hydrogen storage ${ }^{30}$.

\section{Conductivity Analysis}

Conductivity analysis was recorded by using AC780-Conductivity Meter i-SOLV at room temperature. The electrical conductivity of variations in the ratio of Graphene/N-Graphene is greater than the electrical conductivity of the variation of Graphite/N-Graphene. This possible because N-Graphene was deposited into the structure of graphene and the addition of $\mathrm{N}$-Graphene will increase the value of electrical conductivity of graphene because of the possibility that nitrogen-degraded graphene has a better surface, increasing hydrophobicity and electrolyte dispersion on electrodes is better so that it can improve the electrical conductivity and electron transfer rate of graphene.

Table-5: Conductivity Analysis

\begin{tabular}{c|c|c|c|c|c}
\hline \multirow{2}{*}{ Sample } & \multirow{2}{*}{ Comparison } & \multicolumn{4}{|c}{ Measurement of Conductivity $(\mu \mathrm{s} / \mathrm{cm})$} \\
\cline { 3 - 6 } & & $\mathrm{P} 1$ & $\mathrm{P} 2$ & $\mathrm{P} 3$ & Average \\
\hline Commercial Battery Cathode & - & 80.98 & 80.98 & 80.98 & 80.98 \\
\hline Graphite & - & 79.17 & 79.17 & 79.15 & 79.16 \\
\hline Graphite Oxide & - & 69.36 & 69.36 & 69.33 & 69.35 \\
\hline Graphene & - & 858.21 & 858.21 & 858.21 & 858.21 \\
\hline N-Graphene & - & 1157.33 & 1157.33 & 1157.31 & 1157.32 \\
\hline \multirow{3}{*}{ Graphite/N-Graphene } & $1: 1$ & 230.60 & 230.60 & 230.60 & 230.60 \\
\cline { 2 - 6 } & $2: 1$ & 102.70 & 102.70 & 102.70 & 102.70 \\
\cline { 2 - 6 } & $1: 2$ & 350.30 & 350.30 & 350.0 & 350.20 \\
\hline \multirow{3}{*}{ Graphene/N-Graphene } & $1: 1$ & 868.27 & 868.27 & 868.27 & 868.27 \\
\cline { 2 - 6 } & $2: 1$ & 878.18 & 878.17 & 878.18 & 878.18 \\
\cline { 2 - 6 } & $1: 2$ & 969.33 & 969.33 & 969.33 & 969.33 \\
\hline
\end{tabular}

\section{CONCLUSION}

$\mathrm{N}-G r a p h e n e$ can be synthesized using graphite as a feedstock at room temperature conditions and ammonia solution as a source of nitrogen atoms. The conductivity of $\mathrm{N}$-Graphene has higher than the graphene is equal to $1157,33 \mu \mathrm{S} / \mathrm{cm}$. This is because $\mathrm{N}$-Graphene is able to change the band gap of graphene because the nitrogen atom can donate electrons into the graphene structure, consequently, graphene produces more active sides and forms $\mathrm{C}-\mathrm{N}$ interaction so as to improve the electrical conductivity and electron transfer rate of graphene. And on the various composite comparison, Graphite/N-Graphene and Graphene/N-Graphene also have higher conductivity when compared to the cathode in the primary battery. Therefore, based on the magnitude of the conductivity value of $\mathrm{N}$ Graphene it is expected to improve the performance of the primary battery so that it has a longer durability and does not produce hazardous waste.

\section{ACKNOWLEDGMENT}

We would like to thank for the University of Sumatera Utara who supported this research (Hibah TALENTA No: 345/UN5.2.3.1/PPM/KP-TALENTA USU/2018). We also would like thankful to PT Lab Sistematika Indonesia and PT. Gestrindo-Jakarta who supported on SEM-EDX and XRD analysis.

\section{REFERENCES}

1. H. Pinto, A. Markevich. Beilstein Journal of Nanotechnology., 5, 1842(2014), DOI:10.3762/bjnano.5.195.

2. A.K. Geim, K.S.Novoselov, Nature Materials., 6, 1(2007), DOI:10.1038/nmat1849.

3. R.B. Kohakade, E. S. Kumar, R.W. Gaikwad, S. Raghu, R.A. Kalaivani, Rasayan J. Chem., 10(4), 1151(2017), DOI:10.7324/RJC.2017.1041881. 
RASĀYAN $J$. Chem.

Vol. 11 | No. 4 |1649 - 1656| October - December | 2018

4. R.Aarthi, K.C. Lalithambika, Rasayan J. Chem., 7(4), 340(2014),

5. V. Sivasankar, E. S. Kumar, R. S. Babu, S. Raghu, R. A. Kalaivani, Rasayan J. ～Chem., $\quad$ 10(4), 1232(2017), DOI: 10.7324/RJC.2017.1041749

6. E. Casero, A.M. Parra-Alfambra, M.D. Petit-Domínguez, F. Pariente, E. Lorenzo, C. Alonso, Electrochemistry Communications., 20, 63(2012), DOI:10.1016/j.elecom.2012.04.002.

7. C.T.Hsieh, Y.Y Liu, A.K. Roy, Electrochim. Acta., 64, 205(2012), DOI:10.1016/j.electacta.2012.01.019.

8. M.A. Raj,S.A. John, Anal. Chim. Acta.,771, 14(2013), DOI:10.1016/j.aca.2013.02.017.

9. H.H. Chang, C.K. Chang, Y.C. Tsai, C.S.Liao, Carbon., 5, 2331(2012), DOI:10.1016/j.carbon.2012.01.056.

10. H. Li, C. Bubeck, Macromol Research., 21, 290(2013), DOI:10.1007/s13233-013-1139-x.

11. S. Nallusamy, S. Saravanan, V. Kannarasu, M. R. Narayanan, Rasayan J. Chem., 10(4), 1368(2017), DOI: $10.7324 /$ RJC.2017.1041910

12. D. Wang, W. Yan, S.H. Vijapur, G.G. Botte, ElectrochimActa., 89, 732(2013), DOI:10.1016/j.electacta.2012.11.046.

13. C. Tan, J. Rodríguez-Lopez, J.J. Parks, N.L. Ritzert, D.C. Ralph, H.D.Abruna, ACS Nano., 6, 3070 (2012), DOI: 10.1021/nn204746n.

14. Y. Xin, J. Liu, Y. Zhou, W. Liu, J. Gao, Y. Xie, Y. Yin, Z. Zou, Journal of Power Sources., 196, 1012(2011), DOI:10.1016/j.jpowsour.2010.08.051.

15. B. Seger, V.P. Kamat, J. Phys. Chem. C., 113, 7990(2009), DOI:10.1021/jp900360k CCC: \$40.75.

16. A. Bostwick, F. Speck, T. Seyller, K. Horn, M. Polini, R. Asgari, A.H. MacDonald, E. Rotenberg, Science., 328(5981), 999(2010), DOI:10.1126/science.1186489.

17. Q. Wei,X. Tong, G. Zhang, J. Qiao, Q. Gong, S. Sun, Catalysts., 5(3), 1574 (2015), DOI: $10.3390 /$ catal5031574.

18. S. Stankovich, D.A. Dikin, R.D. Piner, K.A. Kohlhaas, A. Kleinhammes, Y. Jia, Y. Wu, S.T. Nguyen, R.S. Ruoff, Carbon., 45, 1558(2007), DOI:10.1016/j.carbon.2007.02.034.

19. W.S.Hummers, R.E. Offeman, J. Am. Chem. Soc.,80(6), 1339(1958), DOI:10.1021/ja01539a017.

20. G. Shao, Y. Lu, F. Wu, C. Yang, F. Zeng, Q. Wu, J Mater Sci., 47, 4400(2012), DOI:10.1007/s10853-012-6294-5.

21. Z. Liu, G. Zhang, Z. Lu, X. Jin, Z. Chang, X. Sun, Nano Research., 6, 293(2013), DOI:10.1007/s12274-013-0307-9.

22. R. Siburian, K. Sebayang, M. Supeno, H. Marpaung, Chemistry Select.,1, 1 (2017), DOI:10.1002/slct.201601561.

23. D. Geng, S. Yang, Y. Zhang, J. Yang, J. Liu, R. Li, Applied Surface Science., 257, 9193(2011), DOI:10.1016/j.apsusc.2011.05.131.

24. M. Naebe, I. Wang, A. Amini,H. Khayyam, N. Hameed, L.H. Li, Y. Chen, B. Fox, Scientific Reports., 14(4), 4375 (2014), DOI:10.1038/srep04375.

25. N. Huang,L.H. Lim, C.H. Chia, M.A. Yarmo, M.R. Muhamad, International Journal of Nanomedicine., 6, 3443(2011), DOI:10.2147/IJN.S26812.

26. B.L. Rivas, I. Peric, S. Villegas, B. Ruf, Journal of the Chilean Chemical Society., 53(1), 1356 (2008), DOI:10.4067/S0717-97072008000100003.

27. K.H. Lee, K. J. Oh, J.G. Son, H. Kim, S.S. Lee, ACS Applied Materials and Interfaces, 6(9), 6361(2014), DOI: 10.1021/am405735c.

28. Y. Hernandez Y,V. Nicolosi,M. Lotya,F.M. Blighe,Z. Sun,S. De, I.TMcgovern, B. Holland, M. Byrne, Y.K Gun'Ko, J.J Boland, P. Niraj, G. Duesberg, S. Krishnamurthy,R. Goodhue, J. Hutchison, V. Scardaci, A.C Ferrari, J.N. Coleman, Nature Nanotechnology., 3(9),563(2008), DOI: $10.1038 /$ nnano.2008.215.

29. N.A. Kumar, H. Nolan, N. McEvoy, E.Rezvani, R.L. Doyle, M.E.G. Lyons, G.S. Duesberg, J. Mater. Chem A, 1, 4431(2013), DOI:10.1039/C3TA10337D.

30. X. Fan, W. Peng, Y. Li, X. Li, S.S. Wang, S. Zhang, F. Zhang, Adv Mater., 20, 4490(2008), DOI:10.1002/adma.200801306.

[RJC-5007/2018] 